\title{
Development of Guided Inquiry Based Learning Materials Enriched with Augmented Reality in Electrolysis Cell Material
}

\author{
https://doi.org/10.3991/ijim.v14i12.15597 \\ Nevia Pradani, Munzil ( $₫$ ), M. Muchson \\ Universitas Negeri Malang, Malang, Indonesia \\ munzil.fmipa@um.ac.id
}

\begin{abstract}
In electrolysis cell chemistry learning material students still experience Difficulties related to chemical material roommates characteristics include three levels of representation macroscopic, submicroscopic, and symbolic. Therefore, the chemistry should be taught by inquiry strategies must be supported a program that is Able to visualize particulate material aspects in an electrolytic cell, such as Augmented Reality. The purpose of this study was to produce guided inquiry-based teaching materials assisted by Augmented Reality on the topic of electrolysis cells. . The development of teaching materials is Carried out in three stages namely (1) analysis phase, (2) design phase, and (3) development stage. Teaching materials are validated by three expert validator. The results of the validation Obtained a percentage of $87.6 \%$ for aspects of the assessment in terms of media, $86.1 \%$ for aspects of the assessment in terms of material and $87.4 \%$ for the readability test. This indicate that the chemistry teaching material that has been developed is included in the very feasible category so that it can be used as a support in learning activities electrolysis cell material.
\end{abstract}

Keywords-Augmented Reality, Electrolysis Cell, Guided Inquiry

\section{Introduction}

One of the goals of chemistry learning is to train students in the science process skills. Learning science such as chemistry is very important because it can practice science process skills or inquiry skills to solve problems in students. Therefore, the science process skills need to be developed. Trianto [11] states that science process skills have an important role that is to help students learn to develop their minds, provide opportunities for students to make discoveries, be able to improve memory, and assist in learning science concepts. The science process skills in students can be trained by developing inquiry-based learning strategies. Inquiry learning is learning that emphasizes the process of finding a concept so that it can improve the science process skills and learning motivation. The implementation of guided inquiry models can make the learning process more meaningful because students become more active, can increase understanding in linking findings and concepts and be able to improve the ability to think critically and inquiry [13]. 
One component supporting the implementation of inquiry-based learning strategies is the development of teaching materials. To date many inquiry-based teaching materials have been developed. However, the implementation of these teaching materials still raises other problems. One characteristic of chemistry learning is that it requires understanding to reach three levels of representation. The problem as stated above appears in one of the chemical materials, namely electrolysis cells. Herawati's research results [3] revealed that chemistry learning currently only focuses on two levels of representation, namely macroscopic and symbolic representations so students tend to memorize abstract concepts. This results in students not being able to understand the processes that occur at the particulate level. One effective method to accommodate the need for teaching materials to support submicroscopic aspects is to present three-dimensional visualization, one of which uses the help of Augmented Reality technology. AR technology is able to visualize the representation of concepts with abstract or particulate representations in three dimensions.

Augmented Reality can also be applied in the world of education. Karen Hamilton and Jorge Olenawa in [10] revealed that the application of technology Augmented Reality has advantages in the field of education including: (a) it can create contextual learning in learning skills; (b) can realize the concepts learned; (c) can create better learning conditions; (d) can be applied to different learning models; (e) learners can find discoveries in their own way; and (f) there are no consequences if an error occurs during the learning process.

Ida Wuryandari, and Albarda [4] who used AR technology to study hydrocarbon bonds in chemical learning to improve student understanding. Kerawalla [7] revealed that AR can increase students' motivation in applying the real environment from a variety of new perspectives. Agree with Chang [2] revealed that AR is able to contribute in increasing students' motivation in learning. Based on these explanations, AR has an important role in the learning process because it can increase students' motivation in learning and finding information related to learning material. AR technology is a beneficial technology in the process of teaching and learning activities. Through teaching materials that are equipped with this AR, students are invited to turn images or abstract objects into semi-real [14].

In its application this application uses instructional media wherein there are markers in teaching materials that will display objects in three dimensions (3D) when scanned. This application was made to make it easier for high school students to learn electrolysis cell material, with a good appearance, material and operations so that it is expected that this application can be accepted to further be applied as a learning medium.

However, this AR technology also has advantages and disadvantages. The advantages possessed include; 1) More interactive, 2) Effective in use, 3) Can be widely implemented in a variety of media, 4) Simple object modeling, because it only displays a few objects, 5) Easy to operate. In addition, AR also has the advantage to attract students' attention in learning, be able to create a collaborative learning atmosphere, and make students more independent [14]. The use of AR is also able to help students' cognitive processes because the process also involves the senses of the eye 
[5], [6]. While the drawbacks are 1) Sensitive with changing viewpoints, 2) Not too much maker, 3) Requires a lot of memory on the equipment installed.

The purpose of this development is producing a guided inquiry-based chemical teaching material enriched by Augmented Reality on electrolysis cell material. In addition, it is also to find out the validity of the developed teaching material. Validation is done by experts and users, where the expert is a chemistry lecturer while the user is a high school chemistry teacher. Readability test was conducted by 20 students of class XII of SMA Negeri 2 Pare.

\section{Methodology}

Development of teaching materials refers to the development model proposed by Lee and Owens [9], which consists of five stages, including: 1) assessment / analysis which includes needs assessment and front-end analysis, 2) design, 3) development, 4) implementation, and 5) evaluation. The design of the development of structured products in Figure 1.

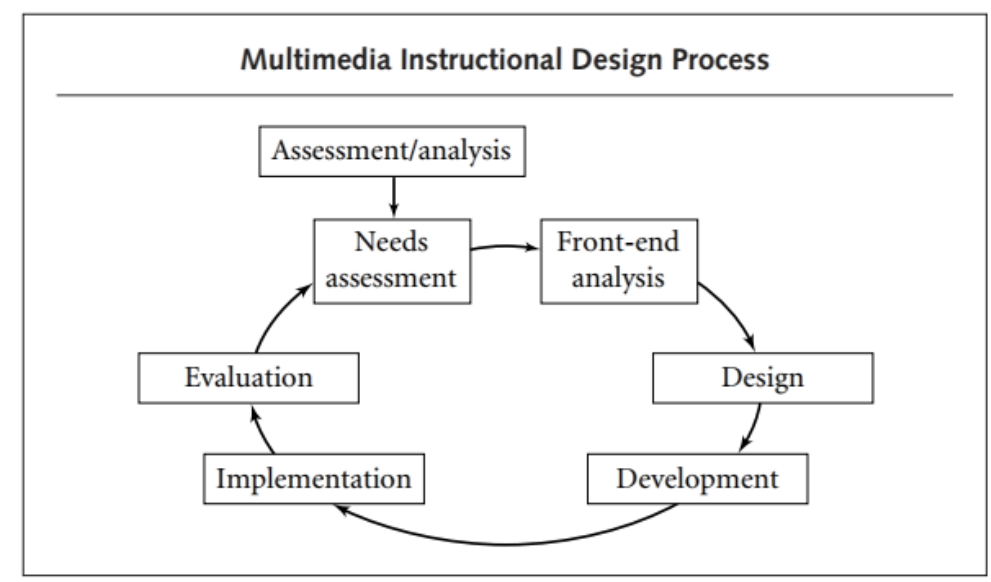

Fig. 1. Development Procedure Lee \& Owens (2004)

This development is only carried out until the third stage, namely development. The implementation and evaluation stages were not carried out because of the limited time, cost and research staff. The stages in this development model are as follows.

\subsection{Assessment / Analysis}

Phase assessment / analysis is divided into 2 phases Needs Assessment and the phase of the Front-End Analysis [9].

Needs Assessment: This stage is done by interview and observation methods. Interviews and observations aim to find out the learning activities and learning resources used during the learning process at school. 
Front-End Analysis: Phase front-end analysis consists of several steps: Audience Analysis, Technology Analysis, Task Analysis, Critical-Incident and Issue Analysis, Objective Analysis, and Media Analysis.

\section{Design}

This design phase is a product planning stage in the form of a storyboard that will be developed into a chemical teaching material product. This stage can be done after obtaining the data or information needed for development in the previous stage. This stage includes the activities of making storyboards, designing product specifications and designing the structure of the material developed in teaching materials.

\section{Development}

This stage is the stage of developing teaching materials into a real product in accordance with the designs that have been previously designed.

Data collection instruments using a questionnaire that was prepared using a Likert scale. The questionnaire used for the assessment included two types of questionnaires, the first instrument was for experts and users while the second instrument was used for readability testing. Data obtained from the results of the validation and readability test were analyzed using the following formula.

$$
\mathrm{P}=\frac{\sum x}{\sum x \mathrm{f}} \times 100 \%
$$

Information:

P: Percentage score

$\Sigma x$ : Total score answers from validator

$\sum X i$ : Maximum score if all validators give a very decent score

The score obtained in the form of a percentage scale indicates that the teaching material is appropriate or needs to be revised. The criteria for determining the eligibility of teaching materials can be seen in Table 1 .

Table 1. Eligibility Criteria Subjects

\begin{tabular}{|c|l|}
\hline Percentage (\%) & Criteria \\
\hline $0 \%-20 \%$ & Not feasible \\
$21 \%-40 \%$ & Less worthy \\
$41 \%-60 \%$ & fairly decent \\
$61 \%-80 \%$ & worthy \\
$81 \%-100 \%$ & very Decent \\
\hline
\end{tabular}




\section{$5 \quad$ Result and Discussion}

The product of this development is in the form of teaching materials in the form of A6-sized pocket books equipped with AR. Teaching materials consist of two components, namely supporting components and content components. Supporting components consist of a cover or cover, preface, table of contents, instructions for use, basic competencies, learning objectives, concept maps, chemical info, let's get to know, bibliography, and profile page. The content component includes content material that consists of three chapters, each chapter consisting of seven levels. Each level is a step in the guided inquiry learning model. The first chapter discusses the basic concepts of electrolysis cells, the second chapter discusses reactions to electrolysis cells, and the third chapter discusses Faraday's Law. At the end of this teaching material is also equipped with a final evaluation to measure students' understanding of the electrolysis cell material that is equipped with features students can see the score obtained and the answer key after working on the evaluation.

Based on the development procedure according to Lee \& Owens [9] which consists of several stages, the following results are obtained. In the first stage, the Phase is Assessment / Analysis divided into 2 namely the Needs Assessment stage and the stage Front-End Analysis. The needs assessment phase is carried out using interview and observation methods. Interviews and observations aim to find out the learning activities and learning resources used during the learning process at SMA Negeri 2 Pare. The front-end analysis phase is further divided into several stages, first the audience analysis, based on observations it can be seen how the learning process takes place, students' responses to the teacher, and how students receive the material delivered by the teacher. This information can be used by researchers in adjusting teaching material to be developed.

Second, the Technology Analysis, this stage is an analysis of the availability of technology owned by students. Facilities owned by students are smartphones and laptops. In addition, the wifi network is also available at school. The task analysis phase is carried out in the selection of material to be studied in teaching materials. The material that can be chosen is the material that is considered difficult to be understood by students. The Phase is Critical-Incident and Issue Analysis carried out to determine which material is already understood by students and which material is not yet understood by students, so that by determining material that is already understood and not understood by students the researcher can determine the part of material that must be taught with more dominant and not. This is done to maximize the solution of existing problems. Electrolysis cell material is considered quite difficult because the students' understanding is only at a sufficient stage.

Next, the stage Objective Analysis, Preparation of teaching materials that are developed based on the Basic Competency (KD) pair 3.6 and 4.6 sub-subject electrolysis cells. The selected material is identified in relation to the formulation of learning objectives in accordance with predetermined basic competencies. Phase Media Analysis aims to determine the type of teaching materials that are suitable to be applied in accordance with field conditions. 
This design phase is the product planning stage in the form of a storyboard that will be developed into a chemical teaching material product. At this stage consists of several activities which include the manufacturing of storyboards for teaching materials, designing product specifications and designing the structure of the material developed in these teaching materials. The storyboard that has been made will be consulted and validated by a supervisor who will then be developed into a product of teaching materials.

This development phase is the stage of developing teaching materials into a real product in accordance with the designs that have been previously designed. The development of teaching materials begins with developing the elements in teaching materials in accordance with the design on the storyboard that has been made, ranging from text, audio, video, images, 2D animation and 3D animation. Furthermore, when the developed product is finished, validation is done to the expert validator. Some examples of pictures of teaching materials that have been developed as follows.
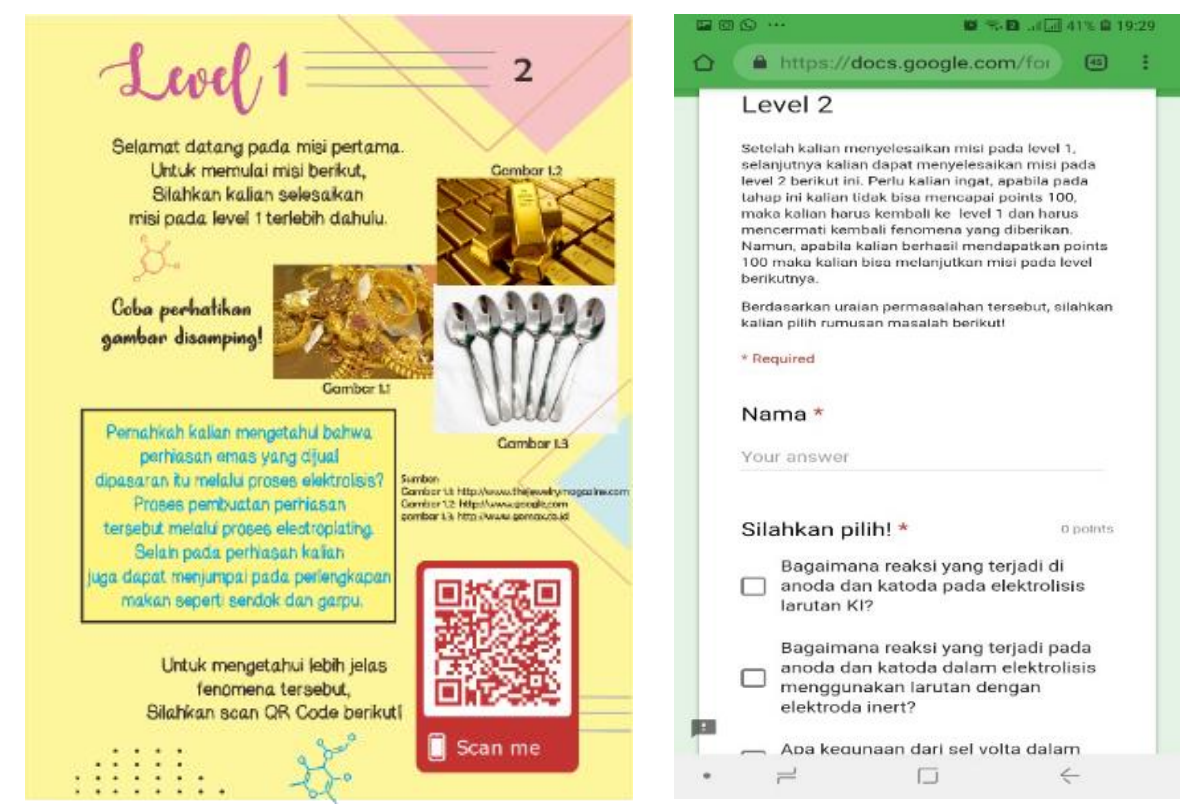

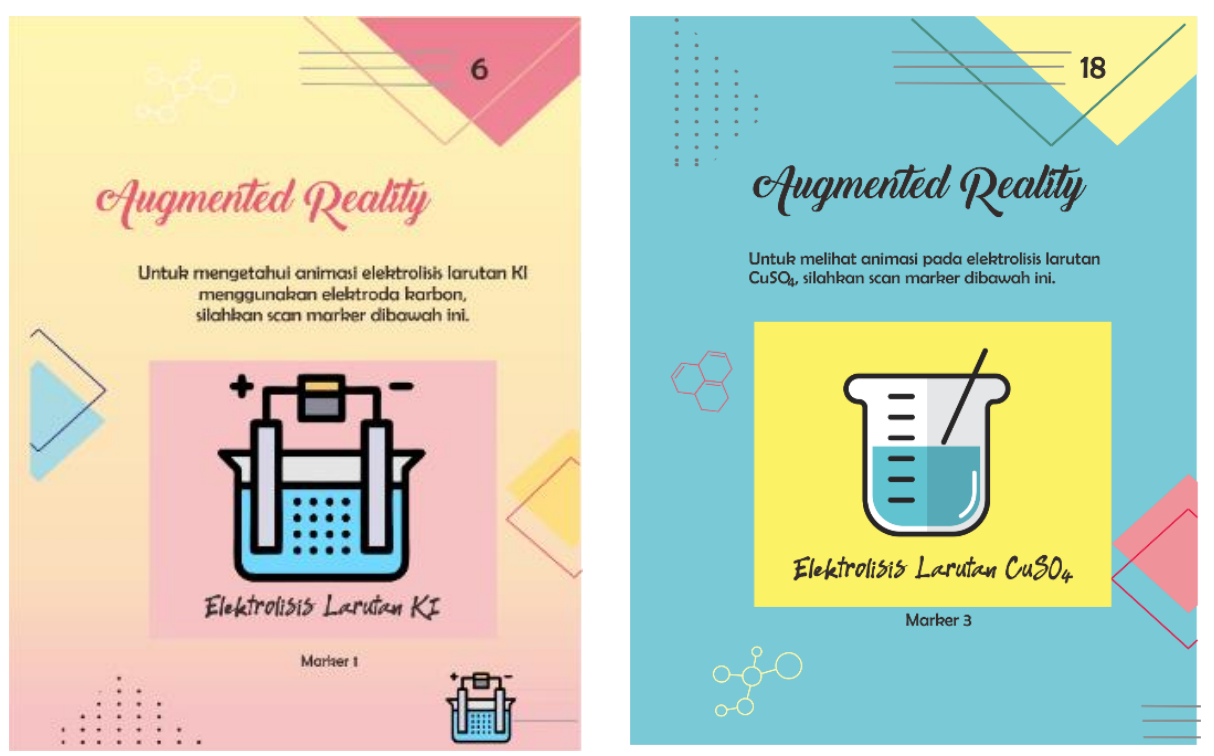

Fig. 2. Some parts of teaching materials

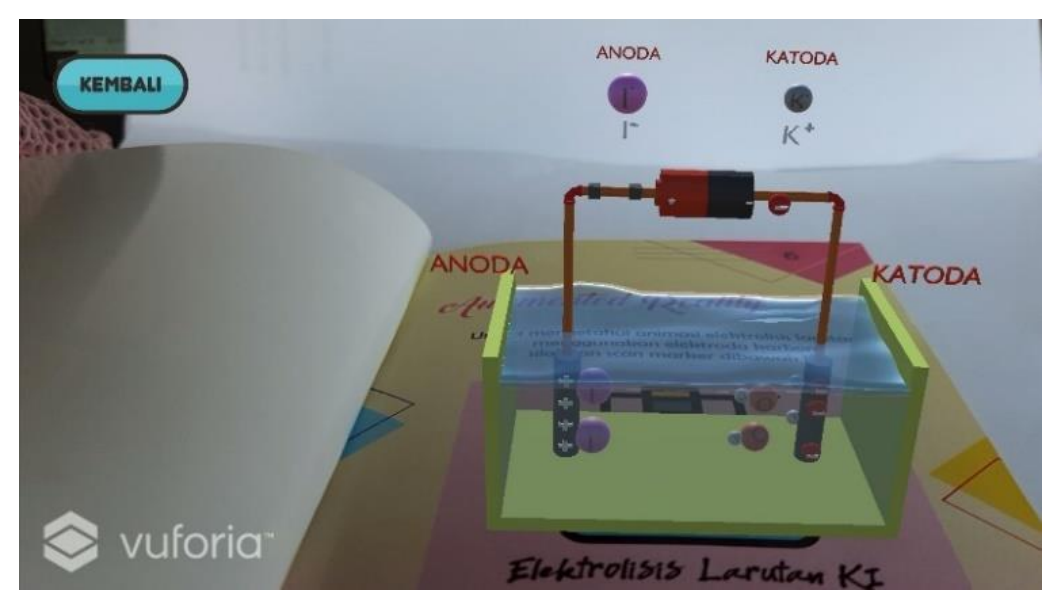

Fig. 3. Animations Augmented Reality of electrolysis KI solution 


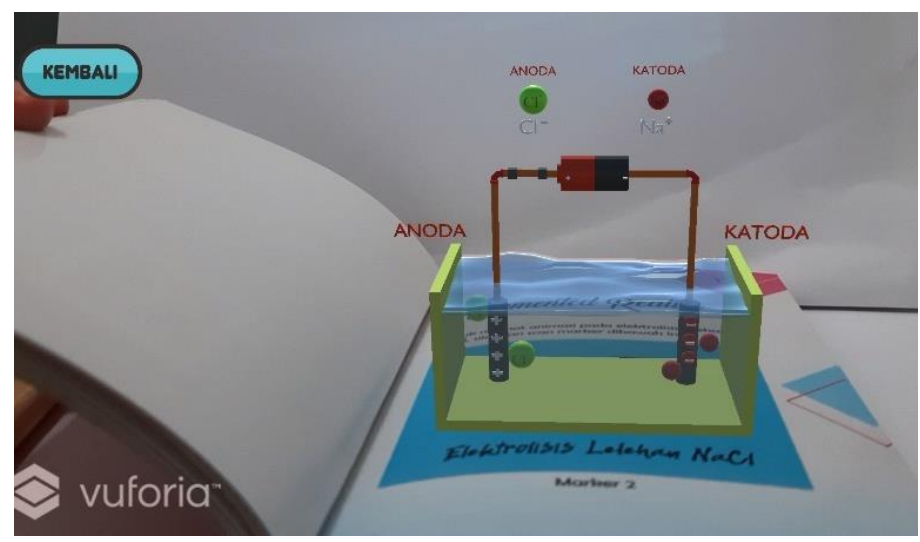

Fig. 4. Animations Augmented Reality of melted of $\mathrm{NaCl}$

The learning steps in the teaching material developed are game based. The steps in learning are made up of many missions, so students are asked to complete missions during the learning process. So, students like playing a game that consists of many missions and must complete each mission given, because in each mission has its own challenges. The involvement of games in learning really helps students to increase motivation in learning. Learning that can be done anywhere with the help of books and mobile phones can increase student motivation and the test can be done easily. Many studies have proven that game-based learning can increase student motivation. the game in learning will make the learning process more fun and able to increase student motivation [8]. Teaching materials created by adding game applicatives can increase learning interest and help students' cognitive processes to learn [1].

The results obtained by quantitative data and qualitative data. Quantitative analysis is done by calculating the average score of scoring from various aspects provided by an expert validator of three people. While qualitative data is obtained from comments and suggestions that have been given and will be used as consideration in making product revisions. Data validation results are presented as follows.

\subsection{Results validation media}

Table 2. Results of Overall Aspect Media Validation by the Third Validator

\begin{tabular}{|c|l|c|l|}
\hline No. & \multicolumn{1}{|c|}{ Rated aspect } & P $(\%)$ & \multicolumn{1}{|c|}{ Criteria } \\
\hline 1 & feasibility Presentation & 88.6 & very Decent \\
\hline 2 & Use of Animation and Augmented Reality & 84.1 & very Decent \\
\hline 3 & presentation Figure & 90.1 & very Decent \\
\hline & Average & 87.6 & very Decent \\
\hline
\end{tabular}

Based on the results of the validation of media experts it can be concluded that this teaching material is very suitable for use in learning electrolysis cell material with a percentage of $87.6 \%$. 


\subsection{Validation results matter}

Table 3. Validation Results Matter of Overall Aspects by Third Validator

\begin{tabular}{|c|l|c|l|}
\hline No. & \multicolumn{1}{|c|}{ Rated aspect } & P (\%) & \multicolumn{1}{|c|}{ Criteria } \\
\hline 1 & Basic Competency (KD) and Learning Objectives & 86.7 & very Decent \\
\hline 2 & Presentation of Concept Maps & 80.0 & worthy \\
\hline 3 & Feasibility of Grammar & 86.7 & very Decent \\
\hline 4 & Sub Material Cycle I: Material Concept Electrolysis Cells & 88.3 & very Decent \\
\hline 5 & Sub Material Cycle II: Material Reaction On Electrolysis Cells & 87.9 & very Decent \\
\hline 6 & Sub Materials III: Faraday's Law Matter & 87.1 & very Decent \\
\hline & Average & 86.1 & very Decent \\
\hline
\end{tabular}

Based on the validation results matter experts concluded that these materials are very appropriate to use the learning materials electrolysis cell with a percentage of $86.1 \%$.

\subsection{Analysis of student readability test results}

After validation by the expert, the reading material can be read out for 20 students of class XII SMAN 2 Pare. Readability test aims to determine the readability of teaching materials. Data obtained from the readability test in the form of quantitative and qualitative data. Data obtained from the readability test is presented in Table 4 below. After validation by experts, these materials can be tested legibility to 20 class XII students of SMAN 2 Pare. Readability test aims to determine the legibility of teaching materials. Data obtained from the test of legibility in the form of quantitative and qualitative data. Data obtained from the legibility test are presented in Table 4 below.

Table 4. Readability Test Results

\begin{tabular}{|c|l|c|l|}
\hline No. & \multicolumn{1}{|c|}{ Rated aspect } & P $(\boldsymbol{\%})$ & \multicolumn{1}{|c|}{ Criteria } \\
\hline 1 & material aspects & 86.9 & Very Decent \\
\hline 2 & aspects of Media & 89.3 & Very Decent \\
\hline 3 & Aspects of Instructional Materials & 88.9 & Very Decent \\
\hline 4 & Aspects of Augmented Reality & 84.6 & Very Decent \\
\hline \multicolumn{2}{|c|}{ Average } & 87.4 & Very Decent \\
\hline
\end{tabular}

Based on the results of the readability test, it can be concluded that this teaching material is very suitable for use in learning electrolysis cell material with a readability percentage of $87.4 \%$. Comments and Suggestions from the results of the readability test by 20 grade XII students of SMAN 2 Pare are shown in Table 5. 
Table 5. Comments and Suggestions Readability Test

\begin{tabular}{|c|l|}
\hline To-student & \multicolumn{1}{c|}{ Comments and Suggestions } \\
\hline 4 & Already following the technology only a few mobile phones do not support the application \\
\hline 5 & The animation is funny and attracts interest in learning electrolysis material \\
\hline 8 & The material presented is good, I can understand easily \\
\hline 12 & The animation is funny and attracts interest in learning electrolysis material \\
\hline 15 & Provides supporting applications to make it easier for users \\
\hline 16 & More and more animation is displayed \\
\hline 19 & More and more animation is displayed \\
\hline
\end{tabular}

\section{Conclusion}

The final form of product that has been developed is guided inquiry-based teaching material enriched by Augmented Reality on electrolysis cell material with a validity of $87.6 \%$ for media validity, $86.1 \%$ for material validity, and $87.4 \%$ for readability testing. This teaching material is in the form of a pocket book in A6 size. In the book consists of three learning chapters, where each chapter consists of seven levels of learning activities which are stages of the guided inquiry model. Learning activities are carried out online by scanning the qr code provided in the book. The book is equipped with learning media such as learning videos, two-dimensional animation, and Augmented Reality animation.

\section{$7 \quad$ Acknowledgement}

This development will not be carried out properly without assistance from various parties. Thank you, the authors say to Dr. Munzil, S.Pd., M.Si., as mentor I and M. Muchson, S.Pd., M.Pd., as mentor II who have guided and provided advice during the process of developing and writing research reports. Dr. H. Yahmin, S.Pd., M.Si., as the validator who has provided criticism and suggestions as an improvement to the teaching material developed. The validator from the teacher, Drs. Hari Budianto, M. Pd. and Drs. Sukaji, M. Si. who have provided many suggestions and input for the improvement of this teaching material, as well as students of class XII SMAN 2 Pare who have been willing to give their time to become subjects of research on legibility test research.

\section{$8 \quad$ References}

[1] Agustini, M., Yurfiarti., Wuryani. 2020. Development of Learning Media Based on Android Games for Children with Attention Deficit Hyperactivity Disorder. International Journal of Interactive Mobile Technologies (iJIM), 14 (6), 205-213. DOI: https://doi.org/10.3991/ijim.v14i06.13401.

[2] Chang, Y.-L., Hou. H. T., Pan, C. Y., Sung, Y. T \& Chang, K. E. 2014. Computers \& Education. Apply an Augmented Reality in a Mobile Guidance to Increase Sense of Place for Heritage Places. Educational Technology \& Society, 18(2), 166-178. 
[3] Herawati, RF, Mulyani, S., \& Redjeki, T., 2013. Multiple Chemical-Based Learning Representation Seen from Initial Capabilities Against Learning Achievement Rate of Reaction Students Sma Negeri I Karanganyar Academic Year 2011/2012. Journal of Chemical Education, 2 (2). From https://media.neliti.com/media/publications/125894-ID-pembelajarankimia-berbasis multiple-rep.pdf.

[4] Ida, W.D., \& Ir. Albarda, M.T. 2009. Perancangan Dan Implementasi Interaksi Media Pembelajaran Hidrokarbon Berbasis Teknologi Augmented Reality. Tesis ITB.

[5] J. Y. Chao and C. H. Liu, "A case study on the spatial conceptualization abilities for sixth grade elementary students from urban, suburban and remote schools," Eurasia J. Math. Sci. Technol. Educ., vol. 13, no. 6, pp. 1675-1686, 2017. https://doi.org/10.12973/ eurasia.2017.00691a

[6] J. Martín-Gutiérrez, P. Fabiani, W. Benesova, M. D. Meneses, and C. E. Mora, "Augmented reality to promote collaborative and autonomous learning in higher education," Comput. Human Behav., vol. 51, pp. 752-761, 2015. https://doi.org/10.1016/j. chb.2014.11.093. https://doi.org/10.1016/j.chb.2014.11.093

[7] Kerawalla, L., Luckin, R., Seljeflot, S., \& Woolard, A. 2006. "Making It Real": Exploring the Potential Of Augmented Reality For Teaching Primary School Science. Virtual Reality, 10(3-4): 163-174. https://doi.org/10.1007/s10055-006-0036-4

[8] Lai, C. H., Jong, B. S., \& Hsia, Y. T. 2020. Applying Concept Map to Game-Base Concept Assessment. International Journal of Interactive Mobile Technologies (iJIM), 14 (6), 159170https://doi.org/10.3991/ijim.v14i06.12057

[9] Lee, W. W., \& Owens, D. L. 2004. Multimedia-Based Instrucsional Design ComputerBased Training Web-Based Training Distance Broadcast Training Performance-Based Solution Second Edition. USA: Pfeiffer.

[10] Septianita, R. 2014. Pengembangan Media Belajar Buku Saku Fisika dengan Teknologi Augmented Reality Berbasis Android pada Materi Fluida Statis untuk Siswa kelas X SMA IPA. Skripsi Tidak Diterbitkan Malang: FMIPA UM. https://doi.org/10.20961 /inkuiri.v7i1.19792

[11] Trianto, 2012. Model Integrated Learning in Theory and Practice. Jakarta: Reader achievement.

[12] Riduwan. 2006. Introduction to Social Statistics. Bandung: Alfabeta.

[13] Ural, Ervim. 2016. The Effect of Guided-Inquiry Laboratory Experiments on Science Education Students' Chemistry Laboratory Attitudes, Anxiety and Achievement. Journal of Education and Training Studies, 4 (4), 217-227. From http://iles.eric.ed.gov. https://doi.org/10.11114/jets.v4i4.1395

[14] Wangid, M. N., Rudyanto. H. E., \& Gunartati. 2020. The Use of AR-Assisted Storybook to Reduce Mathematical Anxiety on Elementary School Students. International Journal of Interactive Mobile Technologies (iJIM), 14 (6), 195-2014. https://doi.org/10.3991 lijim.v14i06.12285.

\section{Authors}

Nevia Pradani is college student in Chemistry Department of Mathematics and Science Faculty of Universitas Negeri Malang, Jl. Surabaya 5 A Malang, Indonesia. (email: nevia.pradani@gmail.com).

Munzil is lecturer in Chemistry Department of Mathematics and Science Faculty of Universitas Negeri Malang, Jl. Surabaya 5 A Malang, Indonesia. His research in- 
Paper-Development of Guided Inquiry Based Learning Materials Enriched with Augmented Reality in...

terest includes: developing model and media of learning, computer and internet-based learning, android based learning (email: munzil.fmipa@um.ac.id).

M. Muchson is lecturer in Chemistry Department of Mathematics and Science Faculty of Universitas Negeri Malang, Jl. Surabaya 5 A Malang, Indonesia. His research interest includes: multimedia interactive, assessment instrument (email: m.muchson.fmipa@um.ac.id).

Article submitted 2020-05-15. Resubmitted --. Final acceptance 2020-05-17. Final version published as submitted by the authors. 